\title{
Primary open-angle glaucoma with retinal vein occlusion: a retrospective case series
}

Muhamad Amin bin Ramli, Sarah Murniati Che Mat, Azhany Yaakub, Embong Zunaina, Liza Sharmini Ahmad Tajudin

Department of Ophthalmology, School of Medical Sciences, Universiti Sains Malaysia, Kubang Kerian, Kelantan, Malaysia

\section{Abstract}

Glaucoma is a known risk factor for retinal vein occlusion (RVO). There are many reported studies among primary open-angle glaucoma (POAG) patients with RVO in Caucasians. Our objective was to report the natural course of RVO in Asian patients with POAG.

A retrospective record review was conducted between January 2015 and December 2016 involving five POAG patients who developed RVO while attending regular follow-up at the Hospital Universiti Sains Malaysia glaucoma clinic (Malaysia). Three readings of intraocular pressure (IOP) were taken as pre-RVO IOP. IOP at presentation of RVO was also recorded. Clinical data including RVO management and complications were documented.

All POAG patients were at the severe and end stage of the disease. None of them achieved target pressure. Median IOP at presentation was $26 \pm 3.8 \mathrm{mmHg}$ (SD) and the majority were asymptomatic. Systemic hypertension was present in all patients. There was deterioration of visual acuity and increased number topical medication post RVO presentation. Vigilant monitoring of IOP is important in POAG patients with systemic hypertension to prevent RVO, given that RVO in POAG is like robbing someone blind twice.

Correspondence: Muhamad Amin bin Ramli, MD (USM), Department of Ophthalmology, School of Medical Sciences, Health Campus Universiti Sains Malaysia,16150 Kubang Kerian, Kelantan, Malaysia.

E-mail: muhamadaminramli@gmail.com 
Keywords: glaucoma, ocular hypertension, intraocular pressure (IOP), retinal vein occlusion (RVO)

\section{Siri kes retrospektif: Glaukoma sudut terbuka Primer dengan oklusi vena retina}

\section{Abstrak}

Glaukoma adalah faktor risiko yang sudah diketahui bagi oklusi vena retina (RVO). Terdapat banyak kajian yang dilaporkan dalam kalangan pesakit glaukoma sudut terbuka utama (POAG) dengan RVO di Caucasians. Objektif kami adalah untuk melaporkan rantaian semula jadi RVO dengan POAG dalam kalangan pesakit di Asia.

Kajian semula rekod secara retrospektif telah dijalankan antara Januari 2015 dan Disember 2016 yang melibatkan lima pesakit POAG yang mengalami RVO semasa menjalani pemeriksaan ulangan di klinik glaukoma Hospital Universiti Sains Malaysia (Malaysia). Tiga bacaan tekanan intraokular (IOP) telah diambil sebagai pra-RVO IOP. IOP semasa peristiwa RVO berlaku juga direkodkan. Data klinikal termasuk pengurusan RVO dan komplikasi telah didokumenkan.

Semua pesakit POAG ini berada pada tahap teruk dan akhir bagi penyakit glaukoma. Tiada seorang pun daripada mereka yang mencapai tekanan sasaran. Median IOP pada detik peristiwa CVO berlaku adalah $26 \pm 3.8 \mathrm{mmHg}(\mathrm{SD})$ dan majoriti adalah tidak menunjukkan sebarang gejala. Semua pesakit mengidap Hipertensi sistemik. Terdapat kemerosotan ketajaman penglihatan dan peningkatan jumlah ubat-ubatan topikal selepas berlakunya RVO. Bagi mencegah RVO, kawalan ketat terhadap IOP adalah penting dalam kalangan pesakit POAG yang juga pengidap hipertensi sistemik. Pesakit POAG yang mengalami RVO boleh diibaratkan seperti merampas deria penglihatan mereka sebanyak dua kali.

Kata kunci: glaukoma, hipertensi okular, tekanan intraokular (IOP), oklusi urat retina $(\mathrm{RVO})$

\section{Introduction}

The association of retinal vein occlusion (RVO) and primary open-angle glaucoma (POAG) has been a subject of interest since 1913. ${ }^{1}$ Most studies found a positive association between RVO and uncontrolled intraocular pressure (IOP) in glaucoma or ocular hypertension (OHT) patients..$^{2-4}$ Based on the Beaver Dam Eye Study, 
glaucoma was found to increase the risk of central retinal vein occlusion (CRVO) 10.7 fold $(95 \% \mathrm{Cl} 3.74,30.67) .{ }^{5}$ The incidence of RVO in glaucoma and OHT has been reported between $10 \%$ and $16 \%$, respectively. ${ }^{2,6,7}$ The incidence of RVO in the Ocular Hypertension Study (OHTS) was $1.4 \%$ over 9.1 years of follow-up. ${ }^{8}$

The OHTS found that the incidence of RVO in the non-treated group was higher than in the treated group, but without statistically significant difference. ${ }^{8}$ On the contrary, there was no direct relationship between IOP and RVO in glaucoma patients. ${ }^{9}$ There were also reported cases of asymptomatic RVO in glaucoma patients. ${ }^{10}$ To complicate matters, it was found that the contralateral eye progressed faster in bilateral glaucoma patients with unilateral BRVO. ${ }^{11}$ In addition, thinner retinal nerve fibre layer (RNFL) thickness was detected in the contralateral eye with unilateral RVO. ${ }^{9}$ Detection and follow-up is important in glaucoma patients with RVO.

Most studies reported cases of Caucasians with RVO in POAG. There is minimal evidence in Asians. ${ }^{12}$ Several studies conducted in different Asian countries showed variations in RVO prevalence, which may be due to racial, environmental, or methodological differences. ${ }^{12}$ Understanding the natural course of RVO in Asian patients with POAG is important in planning an effective strategy for blindness prevention in the Asian region. The aim of this report was to study the natural course of RVO in Asians patients with POAG.

\section{Materials and methods}

A retrospective record review was conducted on POAG patients who attended the glaucoma clinic at the Hospital Universiti Sains Malaysia (Kelantan, Malaysia) between January 2015 and December 2016. POAG patients who were on regular follow-up were included. POAG was diagnosed based on structural and functional criteria according to the World Glaucoma Consensus. ${ }^{13}$ Those who were not known to have POAG during RVO presentation or POAG diagnosed after RVO presentation were excluded. Those who developed RVO due to other causes, such as systemic blood disorder, were also excluded. Blood investigations such as full blood panel and erythrocyte sedimentation rate were conducted. Patients with more than $30 \%$ of missing data were also excluded. A total of ten POAG patients with RVO were identified. However, three patients were excluded due to unclear status of POAG diagnosis and another two patients due to having more than $30 \%$ of missing data.

The diagnosis of ischemic or non-ischemic RVO was based on clinical presentation: visual acuity, presence of relative afferent pupillary defect, iris neovascularization, and fundus findings (degree and extent of retinal haemorrhage, cotton wool spots, degree of retinal vessel dilatation and tortuosity, and presence of collaterals or neovascularization). ${ }^{14} \mathrm{RVO}$ includes CRVO, hemiretinal vein occlusion (HRVO), and BRVO. ${ }^{15}$

Data extracted from the medical records includes demographic data, clinical presentation of both POAG and RVO, and management, including the final visual 


\section{$\mathrm{mmHg} \quad$ IOP Progression}

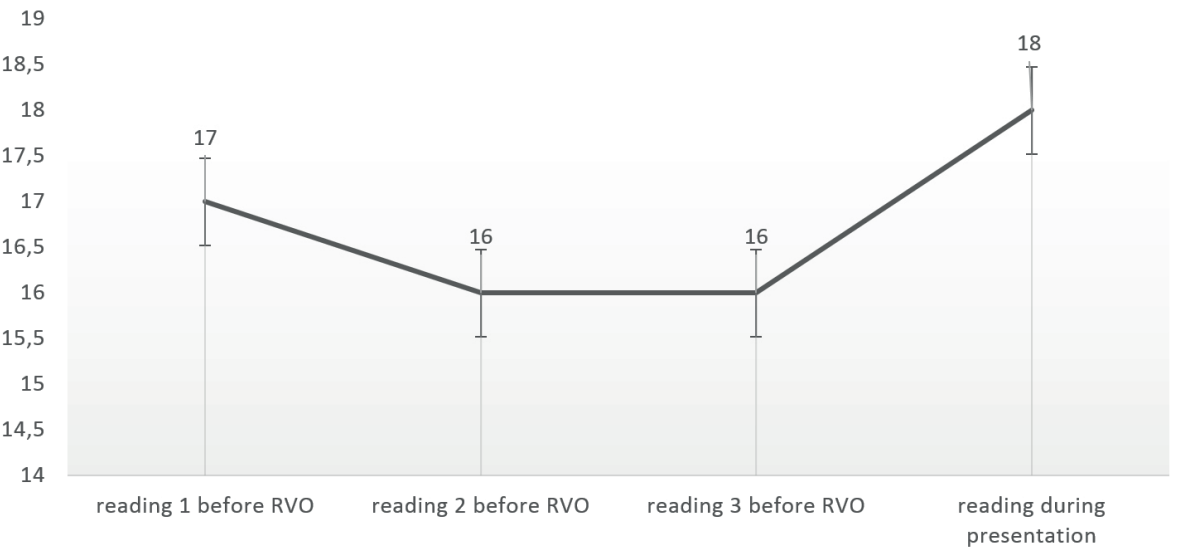

Median IOP

Fig. 1. Median IOP at RVO presentation and three IOP readings pre-RVO.

outcome. These include three consecutive IOP measurements taken prior to RVO presentation (during POAG follow-up period), known in this study as pre-RVO IOP. IOP was measured using Goldmann applanation tonometry. Visual acuity was recorded at RVO presentation and the latest follow-up. Complications, such macular oedema, and RVO and POAG management, including investigating other possible causes of RVO, was also documented. Median IOP was calculated at RVO presentation and three consecutive visits prior to development of RVO.

\section{Results}

Five subjects were included in this study: two men and three women, with a mean age of $70 \pm 3.7$ years (SD) (Table 1). Systemic hypertension was present in all subjects (Table 1). Based on clinical presentation, three developed CRVO, one developed HRVO, and one developed BRVO (Table 1). In Case 2, RVO developed in an already blind eye (NPL) due to POAG.

IOP measurements ranged between $17 \mathrm{mmHg}$ and $26 \mathrm{mmHg}$ at presentation (Table 2). There was an increasing trend of IOP prior to RVO presentation but none reached above $20 \mathrm{mmHg}$ (Fig. 1 ). The highest IOP at presentation of RVO was 26 $\mathrm{mmHg}$ (Table 2). Clinical evidence of neovascularization is absence except for Case 4 (Table 2). There was an increase in the number of pressure-lowering drugs required post RVO in all subjects except for Case 2 . Two subjects developed macular oedema requiring intravitreal ranibizumab injection. 
Table 1. Summary of patient characteristics at presentation RVO

\begin{tabular}{|l|l|l|l|l|l|l|l|l|l|l|l|}
\hline Case & Age & Sex & Ethnicity & $\begin{array}{l}\text { Duration } \\
\text { POAG } \\
\text { (months) }\end{array}$ & & & & $\begin{array}{l}\text { Type of } \\
\text { RVO/ } \\
\text { Laterality }\end{array}$ & & Type & \multicolumn{2}{l|}{$\begin{array}{l}\text { Systemic } \\
\text { Disease }\end{array}$} & \multicolumn{2}{l|}{$\begin{array}{l}\text { BCVA During } \\
\text { RVO }\end{array}$} & \multicolumn{2}{l}{$\begin{array}{l}\text { VCDR } \\
\text { Hypertension }\end{array}$} & OD & OS & OD & OS \\
\hline 1 & 70 & F & Chinese & 36 & CRVO OD & ischemic & Yes & $6 / 12$ & $6 / 6$ & 0.8 & 0.7 \\
\hline 2 & 74 & M & Chinese & 9 & CRVO OS & ischemic & Yes & $6 / 30$ & NPL & 0.9 & 1.0 \\
\hline 3 & 71 & M & Malay & 24 & CRVO OS & ischemic & Yes & $6 / 7.5$ & CF & 0.6 & 0.9 \\
\hline 4 & 64 & F & Malay & 15 & BRVO OS & ischemic & Yes & $6 / 15$ & CF & 0.9 & 0.95 \\
\hline 5 & 71 & F & Malay & 72 & HRVO OD & non ischemic & Yes & $6 / 24$ & $6 / 7.5$ & 0.6 & 0.8 \\
\hline
\end{tabular}

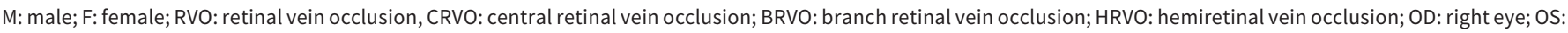
left eye; VCDR: vertical cup-to disc-ratio; BCVA: best corrected visual acuity; CF: counting finger; NPL: no perception to light 
Table 2. Summary of ocular findings and management of RVO

\begin{tabular}{|c|c|c|c|c|c|c|c|c|c|c|c|c|c|c|c|c|}
\hline \multicolumn{10}{|c|}{ IOP pre-RVO and RVO } & \multicolumn{7}{|c|}{ Management and final outcome } \\
\hline \multirow[t]{2}{*}{ Case } & \multirow[t]{2}{*}{ RVO } & \multicolumn{2}{|c|}{$\begin{array}{l}\text { IOP } \\
\left(1^{\text {st }}\right. \\
\text { pre-RVO) }\end{array}$} & \multicolumn{2}{|c|}{$\begin{array}{l}\text { IOP } \\
\left(2^{\text {nd }}\right. \\
\text { pre-RVO) }\end{array}$} & \multicolumn{2}{|c|}{$\begin{array}{l}\text { IOP (3rd } \\
\text { pre-RVO) }\end{array}$} & \multicolumn{2}{|c|}{$\begin{array}{l}\text { IOP (at } \\
\text { presentation) }\end{array}$} & \multirow[t]{2}{*}{$\begin{array}{l}\text { NV } \\
\text { Present }\end{array}$} & \multirow[t]{2}{*}{ PRP } & \multirow[t]{2}{*}{$\begin{array}{l}\text { Macular } \\
\text { oedema }\end{array}$} & \multicolumn{2}{|c|}{$\begin{array}{l}\text { Number of } \\
\text { glaucoma } \\
\text { medications }\end{array}$} & \multicolumn{2}{|c|}{$\begin{array}{l}\text { Final } \\
\text { BCVA }\end{array}$} \\
\hline & & OD & OS & OD & OS & OD & OS & OD & OS & & & & $\begin{array}{l}\text { Pre- } \\
\text { RVO }\end{array}$ & $\begin{array}{l}\text { Post- } \\
\text { RVO }\end{array}$ & OD & OS \\
\hline 1 & OD CRVO & 17 & 19 & 26 & 18 & 20 & 16 & 26 & 20 & NO & YES & YES & 3 & 4 & HM & $6 / 6$ \\
\hline 2 & OS CRVO & 10 & 12 & 12 & 10 & 38 & 40 & 20 & 22 & NO & YES & NO & 3 & 1 & HM & NPL \\
\hline 3 & OS CRVO & 18 & 16 & 14 & 18 & 14 & 14 & 16 & 18 & NO & NO & YES & 4 & 4 & $6 / 6$ & $3 / 60$ \\
\hline 4 & OS BRVO & 14 & 15 & 18 & 26 & 14 & 16 & 16 & 18 & YES & YES & NO & 2 & 4 & $6 / 6$ & PL \\
\hline 5 & OD HRVO & 18 & 13 & 14 & 14 & 16 & 14 & 17 & 16 & NO & YES & NO & 1 & 2 & $6 / 9$ & $6 / 6$ \\
\hline
\end{tabular}

RVO: retinal vein occlusion, BRVO: branch retinal vein occlusion; HRVO: hemiretinal retina vein occlusion; OD: right eye; OS: left eye; IOP: intraocular pressure; NV: new vessel; PRP: panretinal photocoagulation; VA: visual acuity, BCVA: best corrected visual acuity; HM: hand movement; CF: counting finger; NPL: no perception to light 


\section{Discussion}

Most POAG patients who developed RVO were at advanced and end stage (based on VCDR) and none of them achieved target pressure based on the three readings of pre-RVO IOPs. However, the median IOPs pre-RVO did not reach more than 20 $\mathrm{mmHg}$. In fact, there was a slight reduction in median IOP prior to RVO presentation. Due to the retrospective nature of the study, the measurement of IOP pre-RVO presentation was not standardized in terms of intervals and times taken. Diurnal IOP variation was not addressed.

IOP elevation is believed to be the risk factor for RVO due to compression and collapse of the central retinal vein. ${ }^{1}$ In pre-existing glaucoma, IOP at CRVO presentation was higher with a mean of $21.7 \mathrm{mmHg}$ compared to the non-pre-existing glaucoma group $(13.9 \mathrm{mmHg}){ }^{16}$ In this study, the highest recorded IOP during RVO presentation was $26 \mathrm{mmHg}$, due to all patients being on topical lowering-pressure drugs. Currently, IOP elevation is no longer exponentially related to RVO. ${ }^{2}$ Furthermore, there was no statistically difference in RVO prevalence between treated and non-treated OHT patients. ${ }^{8}$ Mean IOP of OHT with BRVO was slightly higher than OHT without RVO, but was not statistically significant. ${ }^{17}$ However, no studies show that reaching target IOP prevents RVO or prevents RVO in the contralateral eye in pre-existing POAG/OHT with RVO.

Systemic hypertension has a strong correlation with RVO and open-angle glaucoma. ${ }^{18}$ In our case series, systemic hypertension was present in all cases. It has been reported that $60 \%$ of RVO patients were hypertensive patients. ${ }^{19}$ According to Hayreh et al., there was a significantly higher prevalence of arterial hypertension in BRVO compared with CRVO and HRVO. ${ }^{20}$ However, there are no studies so far showing a pressure trend before the development of RVO. We have not documented blood pressure control in our subjects. In addition, increasing age is exponentially related to the prevalence of both diseases. ${ }^{18}$ The median age was 71 years old in this series. Perhaps, there is a connection between age, systemic hypertension, and these two blinding ocular diseases: RVO and POAG.

All our patients demonstrated deterioration of visual acuity post RVO except for Case 5. Good visual acuity in this patient was likely due to non-ischaemic HRVO without macular involvement. Final visual acuity outcome was affected by the type of RVO. ${ }^{21}$ Non-ischaemic RVO has better visual prognosis. ${ }^{21}$ However, $34 \%$ of non-ischemic CRVO can convert to ischemic type within three years. ${ }^{14,22}$ Interestingly, none of the subjects developed clinical evidence of neovascularization except for Case 4 with BRVO. Varying degrees of retinal ischaemia due to non-perfusion of retinal capillaries may occur depending on the degree of retinal vein thrombosis.

Standard treatment of the underlying ischemia in RVO includes panretinal photocoagulation (PRP) combined with medical and surgical management for elevated IOP. According to the Central Retinal Vein Occlusion Study Group, PRP should be performed promptly at the first sign of definite neovascularization, but not pro- 
phylactically. ${ }^{7}$ However, PRP was performed in cases without definite neovascularization in our present case series, not as prophylactic treatment, but due to a high tendency to default follow-up, as they were living in another state. PRP was initiated earlier due to higher risk of ischaemic CRVO to develop neovascular glaucoma, which may lead to more challenging complications. ${ }^{23}$ Currently, intraocular injection of anti-vascular endothelial growth factor has gained popularity in RVO treatment. Several studies have shown its effectiveness in preventing the complications arising from neovascularization. ${ }^{24,25}$ However, this treatment is expensive and requires multiple injections. We reserved this injection as pre-treatment prior to surgical interventions such as glaucoma drainage device implantation.

This retrospective case series may not be the best to reflect RVO in POAG. However, based on this case series, target pressure should be achieved in POAG patients, especially those with systemic hypertension. To the best of our knowledge, there is no recommended target IOP or blood pressure to prevent RVO in POAG. Perhaps, strict monitoring of IOP and blood pressure in POAG patients with systemic hypertension may help prevent the development of RVO.

\section{References}

1. Verhoeff FH. The effect of chronic glaucoma on the central retinal vessels. Arch Ophthalmol. 1913;42:145-152.

2. Hayreh SS, Zimmerman MB, Beri M, Podhajsky P. Intraocular pressure abnormalities associated with central and hemicentral retinal vein occlusion. Ophthalmology. 2004;111(1):133-141.

3. Luntz MH, Schenker HI. Retinal vascular accidents in glaucoma and ocular hypertension. Surv Ophthalmol. 1980;25(3):163-167.

4. Vannas S, Tarkkanen A. Retinal Vein Occlusion and Glaucoma: Tonographic Study of The Incidence of Glaucoma and of Its Prognostic Significance. Br J Ophthalmol. 1960;44(10):583-589.

5. Klein R, Moss SE, Meuer SM, Klein BE. The 15-Year Cumulative Incidence of Retinal Vein Occlusion. Arch Ophthalmol. 2008;126(4):513-518.

6. Blankenship GW, Okun E. Retinal tributary vein occlusion: history and management by photocoagulation. Arch Ophthalmol. 1973;89(5):363-368.

7. Vein T. Natural history and clinical management of central retinal vein occlusion. Arch Ophthalmol. 1997;115:486-491.

8. Barnett EM, Fantin A, Wilson BS, Kass MA, Gordon MO, Ocular Hypertension Treatment Study G. The incidence of retinal vein occlusion in the ocular hypertension treatment study. Ophthalmology. 2010;117(3):484-488.

9. Kim MJ, Woo SJ, Park KH, Kim T-W. Retinal nerve fiber layer thickness is decreased in the fellow eyes of patients with unilateral retinal vein occlusion. Ophthalmology. 2011;118(4):706-710.

10. Na KI, Jeoung JW, Kim YK, Lee WJ, Park KH. Incidence of retinal vein occlusion in open-angle glaucoma: a nationwide, population-based study using the Korean Health Insurance Review and Assessment Database. Clin Exp Ophthalmol. 2018;46(6):637-644. 
11. Lopilly Park HY, Jeon S, Lee MY, Park CK. glaucoma progression in the unaffected fellow eye of glaucoma patients who developed unilateral branch retinal vein occlusion. Am J Ophthalmol. 2017;175:194-200.

12. Shin YU, Cho H, Kim JM, et al. Prevalence and associated factors of retinal vein occlusion in the Korean National Health and Nutritional Examination Survey, 2008-2012: A cross-sectional observational study. Medicine. 2016;95(44).

13. World Glaucoma Association. 10th WGA Consensus - Diagnosis of Primary Open Angle Glaucoma 2016. Available from: https://wga.one/wga/consensus-10/.

14. McIntosh RL, Rogers SL, Lim L, et al. Natural history of central retinal vein occlusion: an evidence-based systematic review. Ophthalmology. 2010;117(6):1113-1123

15. Sivaprasad S, Amoaku W, Hykin P, et al. The Royal College of Ophthalmologists Guidelines on retinal vein occlusions: executive summary. Eye. 2015;29(12):1633.

16. Chen $\mathrm{H}-\mathrm{F}$, Chen M-C, Lai C-C, et al. Neovascular glaucoma after central retinal vein occlusion in pre-existing glaucoma. BMC Ophthalmol. 2014;14(1):119.

17. David R, Zangwill L, Badarna M, Yassur Y. Epidemiology of retinal vein occlusion and its association with glaucoma and increased intraocular pressure. Ophthalmologica. 1988;197(2):69-74.

18. Park HL, Jung Y, Han K, Lee MY, Park CK. Health care claims for primary open-angle glaucoma and retinal vein occlusion from an 11-year nationwide dataset. Sci Rep. 2017;7(1):8038.

19. Shahsuvaryan M. Systemic hypertension and the eye: highlighting a comorbidity. J Clin Exp Cardiolog. 2016;7(442):2.

20. Hayreh SS, Zimmerman B, McCarthy MJ, Podhajsky P. Systemic diseases associated with various types of retinal vein occlusion. Am J Ophthalmol. 2001;131(1):61-77.

21. Hayreh SS, Podhajsky PA, Zimmerman MB. Natural history of visual outcome in central retinal vein occlusion. Ophthalmology. 2011;118(1):119-133

22. The Central Vein Occlusion Study Group. Natural history and clinical management of central retinal vein occlusion. The Central Vein Occlusion Study Group. Arch Ophthalmol. 1997;115:486-491.

23. Magargal LE, Brown GC, Augsburger JJ, Donoso LA. Efficacy of panretinal photocoagulation in preventing neovascular glaucoma following ischemic central retinal vein obstruction. Ophthalmology. 1982;89(7):780-784.

24. Costagliola C, Cipollone U, Rinaldi M, Della Corte M, Semeraro F, Romano MR. Intravitreal bevacizumab (Avastin ${ }^{\oplus}$ ) injection for neovascular glaucoma: a survey on 23 cases throughout 12-month follow-up. Br J Clin Pharmacol. 2008;66(5):667-673.

25. Yazdani S, Hendi K, Pakravan M. Intravitreal bevacizumab (Avastin) injection for neovascular glaucoma. J Glaucoma. 2007;16(5):437-439. 